\title{
Recent Artifact Surface Collections from the M. S. Roberts (41HE8) Mound Site in the Upper Neches River Basin in East
}

\section{Texas}

Timothy K. Perttula

Heritage Research Center, Stephen F. Austin State University

Mark Walters

Heritage Research Center, Stephen F. Austin State University

Follow this and additional works at: https://scholarworks.sfasu.edu/ita

Part of the American Material Culture Commons, Archaeological Anthropology Commons, Environmental Studies Commons, Other American Studies Commons, Other Arts and Humanities Commons, Other History of Art, Architecture, and Archaeology Commons, and the United States History Commons

Tell us how this article helped you.

This Article is brought to you for free and open access by the Center for Regional Heritage Research at SFA ScholarWorks. It has been accepted for inclusion in Index of Texas Archaeology: Open Access Gray Literature from the Lone Star State by an authorized editor of SFA ScholarWorks. For more information, please contact cdsscholarworks@sfasu.edu. 
Recent Artifact Surface Collections from the M. S. Roberts (41HE8) Mound Site in the Upper Neches River Basin in East Texas

\section{Creative Commons License}

(c) (1) (2)

This work is licensed under a Creative Commons Attribution-NonCommercial 4.0 International License 


\title{
Recent Artifact Surface Collections from the M. S. Roberts (41HE8) Mound Site in the Upper Neches River Basin in East Texas
}

\author{
Timothy K. Perttula and Mark Walters
}

\section{INTRODUCTION}

In January 2015, the junior author obtained, with the assistance of the landowners, a surface collection of artifacts from the M. S. Roberts site (41HE8), a long-forgotten ancestral Caddo mound center and settlement in the upper Neches River basin in Henderson County, Texas. This collection of artifacts is discussed in this article, and comparisons are made to the larger assemblage of Caddo ceramic vessel sherds obtained during 1931 investigations at the site by Pearce and Jackson (1931).

\section{Site Setting and Cultural Context}

The M. S. Roberts site (41HE8) is one of only a few known Caddo earthen mound sites in the upper Neches River basin, the most prominent being the A. C. Saunders site (41AN19) on the Neches River to the east (Jackson 1936; Kleinschmidt 1982) and the Middle Caddo period Pace McDonald site (41AN51) on Mound Prairie Creek to the south (Perttula et al. 2011). The M. S. Roberts site is on an alluvial terrace (420 ft. amsl) on the north side of Caddo Creek, an eastward-flowing tributary to the Neches River, about $1.6 \mathrm{~km}$ west of Poynor, Texas (see Perttula and Troell 2016, this volume:Figure 1). The M. S. Roberts site when first reported had a single earthen mound about $24 \times 20 \mathrm{~m}$ in length and width, and it was estimated to stand $1.7 \mathrm{~m}$ in height. A likely borrow pit depression was noted just to the west of the mound. Artifacts were noted and collected by Pearce and Jackson (1931) from the plowed surface of the mound and surrounding Caddo habitation areas on the alluvial terrace.

The mound at the M. S. Roberts site began as a $24 \mathrm{~cm}$ thick deposit of yellow sand built on an alluvial terrace, and an important structure was built and used (for ritual and political purposes, perhaps) there, then eventually burned. At that point the yellow sand mound fill and the burned structure deposits were covered with a more massive mound fill more than $1.1 \mathrm{~m}$ in thickness. The mound was set within a settlement of unknown size and character, and the archaeological evidence of its use is marked by a small assemblage of plain and decorated ceramic vessel sherds and a possible L-shaped elbow pipe sherd in the Texas Archeological Research Laboratory collections at The University of Texas at Austin. These artifacts suggest that the Caddo construction of the mound and occupation of the settlement took place sometime as early as in the first half of the 15th century A.D., and the occupation may have lasted until as late as ca. A.D. 1480, during the first part of the Frankston phase. Radiocarbon dates from the site are very much needed to refine the age of the Caddo occupation, and help establish when the mound feature was constructed, used, and then abandoned. At the present time, only a single other Frankston phase mound is known: the A. C. Saunders site. The mound at the M. S. Roberts site may be the second mound site in a Late Caddo period Frankston phase community in the upper Neches River basin (see Perttula and Troell 2016, this volume).

\section{Artifacts in the Surface Collection}

The surface collection of ancestral Caddo artifacts from the M. S. Roberts site comes from the ca. 30 x $38 \mathrm{~m}$ mound itself (the mound stands about $1.8 \mathrm{~m}$ in height) as well as an associated ca. $100 \times 100 \mathrm{~m}$ 
(ca. 2.5 acres) settlement and habitation areas. The majority of artifacts in the surface collection are sherds $(n=134)$ from ceramic vessels, but there are a few pieces of chipped stone $(n=11)$ also visible on the surface.

\section{Ceramic Artifacts}

There are 134 sherds from plain, utility, and fine ware ceramic vessels in the 2015 surface collection from the M. S. Roberts site (Table 1). Approximately 89 percent of the sherds are from vessels manufactured with grog temper, and the remainder are from bone-tempered vessels.

Table 1. Ceramic sherds in the 2015 surface collection from the M. S. Roberts site.

\begin{tabular}{lccc}
\hline Ware & Grog-tempered & Bone-tempered & $\mathrm{N}$ \\
\hline Plain & 80 & 12 & 92 \\
Utility & 29 & 1 & 30 \\
Fine & 10 & 2 & 12 \\
\hline Totals & 119 & 15 & 134 \\
\hline
\end{tabular}

Of the 10 rim sherds in the collection, six are from plain vessels and the other four are from utility ware jars; there are no rim sherds from fine ware vessels. This indicates that plain and utility ware vessels are particularly abundant in the sherd assemblage, especially compared to the sherds from fine ware vessels. The plain to decorated sherd ratio $(\mathrm{P} / \mathrm{DR})$ is 2.19 , also suggesting that plain ware vessels (and vessels decorated primarily on the rim) are common in the M. S. Roberts site assemblage.

The 42 decorated sherds in the collection are from utility wares ( 71 percent) and fine wares (29 percent) (Table 2). Sherds from vessels with brushed and brushed-incised decorations comprise 20 percent and 10 percent, respectively, of the utility wares. The brushed sherds are from Bullard Brushed vessels with diagonal brushing on the rim (Figure 1a), as well as parallel (Figure 1b) and opposed brushing marks (Figure 1c) on the vessel bodies. The brushed-incised sherds have either parallel brushed and incised marks and lines or parallel brushing marks with overlying incised lines; these sherds may also be from currently unrecognized varieties of Bullard Brushed.

Table 2. Decorative methods and elements represented on the utility ware and fine ware sherds from the M. S. Roberts site.

\begin{tabular}{llll}
\hline $\begin{array}{l}\text { Decorative method/ } \\
\text { decorative element }\end{array}$ & Rim & Body & $\mathrm{N}$ \\
\hline
\end{tabular}

\section{Utility Ware}

Brushed

diagonal brushed marks

overlapping brushed

parallel brushed marks

$\begin{array}{lll}1 & - & 1 \\ - & 1 & 1 \\ - & 4 & 4\end{array}$

\section{Brushed-Incised}

parallel brushed-incised marks and lines

parallel brushed marks and overlying straight incised lines

$\begin{array}{lll}- & 1 & 1 \\ - & 2 & 2\end{array}$

\section{Incised}

cross-hatched lines

diagonal lines

$-$

diagonal opposed lines

2

1

1

4

1 
Table 2. Decorative methods and elements represented on the utility ware and fine ware sherds from the M. S. Roberts site, cont.

\begin{tabular}{|c|c|c|c|}
\hline $\begin{array}{l}\text { Decorative method/ } \\
\text { decorative element }\end{array}$ & Rim & Body & $\mathrm{N}$ \\
\hline parallel lines & - & 5 & 5 \\
\hline straight line & - & 2 & 2 \\
\hline \multicolumn{4}{|l|}{ Punctated } \\
\hline fingernail punctated row/rows & - & 5 & 5 \\
\hline tool punctated row/rows & 1 & 4 & 5 \\
\hline \multicolumn{4}{|l|}{ Fine Ware } \\
\hline \multicolumn{4}{|l|}{ Engraved } \\
\hline hatched zones & - & 2 & 2 \\
\hline horizontal-diagonal lines & - & 1 & 1 \\
\hline sets of opposed lines & - & 1 & 1 \\
\hline parallel lines & - & 3 & 3 \\
\hline straight lines & - & 4 & 4 \\
\hline \multicolumn{4}{|l|}{ Red-slipped } \\
\hline ext. red-slipped & - & 1 & 1 \\
\hline Totals & 4 & 38 & 42 \\
\hline
\end{tabular}

The incised sherds in the 2015 collection have sets of diagonal lines on the rim of utility ware Maydelle Incised jars (see Figure 1g), as well as diagonal opposed or cross-hatched incised elements. Other body sherds have straight or parallel incised lines.

The punctated sherds are from utility ware vessels with either rows of fingernail or tool punctates (see Figure 1d-e). This includes a rim/handle sherd with rows of tool punctations (see Figure 1f). Punctated utility wares in upper Neches River basin Caddo sites have only the most basic decorative elements (Suhm and Jelks 1962:Plate 79a-b).

One of the fine ware sherds in the collection is a body sherd from a bowl or carinated bowl with an ochre-rich red slip on the exterior surface of the vessel (see Table 2). The other fine ware sherds are from carinated bowls and bottles. One sherd from a probable Poynor Engraved carinated bowl has a horizontal engraved line above the carination and a set of closely-spaced diagonal lines that are part of a hatched triangle attachment. A bottle body sherd has a curvilinear zone with hatched engraved lines, while another carinated bowl has a curvilinear hatched triangle attachment (see Figure 1h). Several varieties of Poynor Engraved, including var. Blackburn and var. Cook, have such design elements (Perttula 2011).

\section{Comparisons with the 1931 University of Texas ceramic assemblage}

Both ceramic vessel sherd assemblages from the M. S. Roberts site are from vessels regularly tempered with grog (i.e., crushed sherds), between 86.1-89 percent of the sherds in the collections (Table 3). Plain ware vessels are apparently common in both assemblages, as are sherds from utility ware assemblages. Sherds from fine ware vessels - decorated with engraved line elements or with a red-slipped surface — only comprise between 6.7-9.0 percent of the sherd assemblages, while utility ware sherds decorated with wet paste elements represent between 22.4-34.0 percent of the two collections (Table 3). The only identified fine ware type is Poynor Engraved, the principal post-14 $4^{\text {th }}$ century A.D. fine ware in the upper Neches River basin of East Texas. 


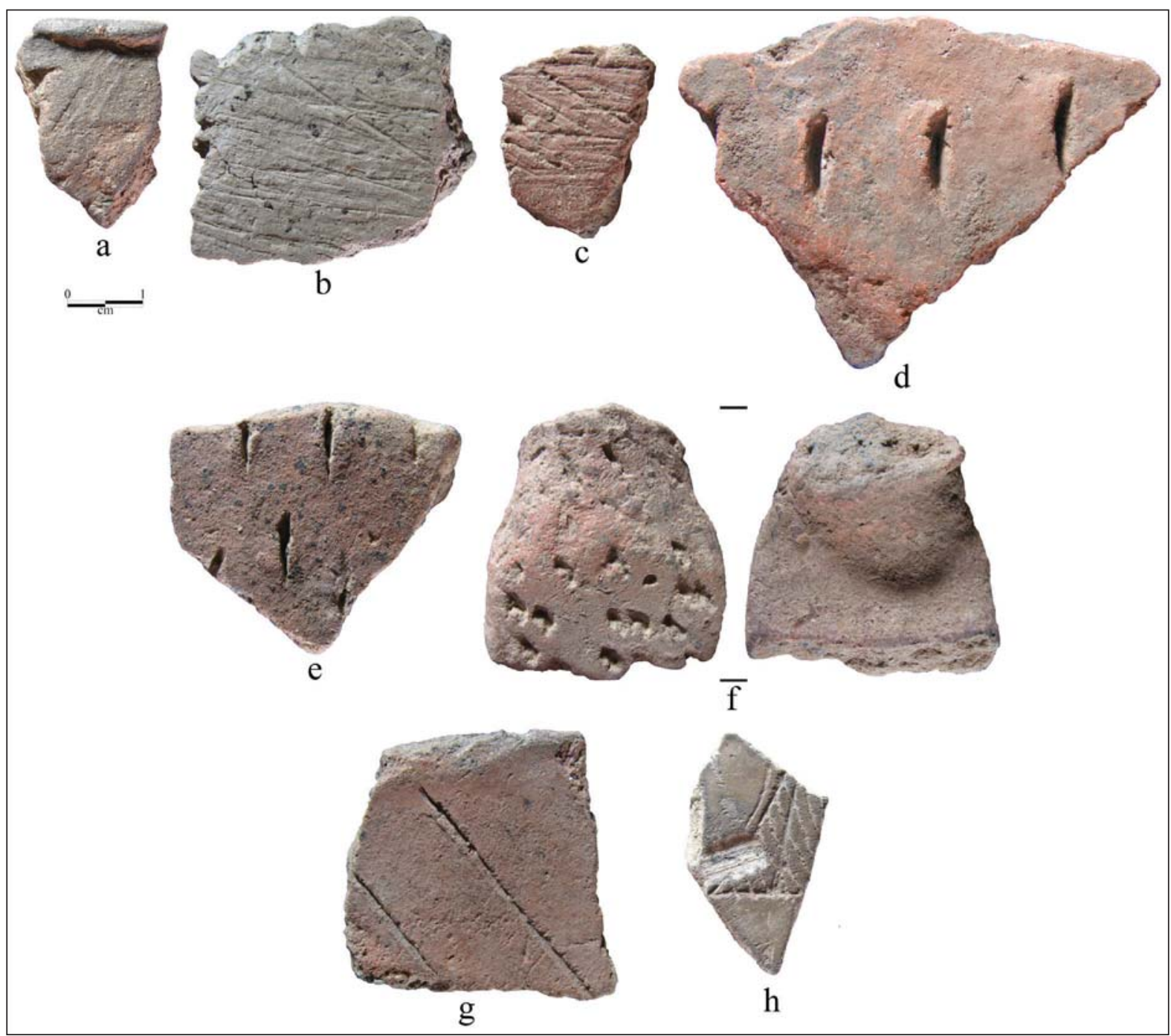

Figure 1. Selected decorated sherds from the M. S. Roberts site (41HE8): a-c, brushed rim or body sherds; d-e, fingernail punctated body sherds; f, punctated rim/handle sherd; g, diagonal incised rim sherd; h, engraved body sherd.

Table 3. M. S. Roberts site (41HE8) ceramic sherd comparisons.

\begin{tabular}{llc}
\hline Attributes & 1931 & 2015 \\
\hline grog-tempered & $86.1 \%$ & $89 \%$ \\
bone-tempered & $13.9 \%$ & $11 \%$ \\
P/DR & 1.52 & 2.19 \\
& & \\
Utility Ware & $\mathbf{3 4 . 0 \%}$ & $\mathbf{2 2 . 4 \%}$ \\
Appliqued & $0.7 \%$ & - \\
Brushed & $6.7 \%$ & $4.5 \%$ \\
Brushed-Incised & $1.2 \%$ & $2.2 \%$ \\
Brushed-Punctated & $0.2 \%$ & - \\
Incised & $12.4 \%$ & $8.2 \%$ \\
Incised-Punctated & $2.4 \%$ & - \\
Punctated & $9.4 \%$ & $7.5 \%$
\end{tabular}


Table 3. M. S. Roberts site (41HE8) ceramic sherd comparisons, cont.

\begin{tabular}{lll}
\hline Attributes & 1931 & 2015 \\
\hline Fine Ware & $\mathbf{6 . 7 \%}$ & $\mathbf{9 . 0 \%}$ \\
Engraved & $5.0 \%$ & $8.2 \%$ \\
Red-slipped & $1.7 \%$ & $0.7 \%$ \\
\hline Totals & 419 & 134 \\
\hline
\end{tabular}

The principal utility wares have either incised (8.2-12.4 percent) or punctated (7.5-9.4 percent) decorative elements, and sherds from Maydelle Incised jars and punctated jars are notable in each assemblage (see Table 3); sherds with incised-punctated decorative elements are not present in the small 2015 surface collection. Sherds from Bullard Brushed vessels with brushed decorative elements represent between 6.78.1 percent of all the sherds in the two collections (see Table 3), and only between 20.5-21.4 percent of the decorated sherds in the 1931 and 2015 assemblages.

\section{Lithic Artifacts}

There is only a small amount of lithic artifacts from the site in the 2015 surface collection. This includes 10 pieces of lithic debris from the manufacture of chipped stone tools and a flake tool used for the cutting and shredding of plant remains or animal bones. The lithic debris is represented by small pieces of chert from local (Neches River) gravels with stream-rolled cortical surfaces: including reddish-brown chert $(\mathrm{n}=1$, 100 percent cortical); light gray chert $(n=1)$; gray chert $(n=5)$; dark gray chert $(n=1)$; and dark grayish-brown chert ( $\mathrm{n}=2,50$ percent cortical). The one chipped stone tool is a cortical gray chert flake tool with unilateral use-wear/retouch; the use-worn area is $10.1+\mathrm{cm}$ in length.

\section{SUMMARY AND CONCLUSIONS}

A 2015 artifact surface collection from the M. S. Roberts site (41HE8) in the upper Neches River ba$\sin$ in East Texas contains both ceramic vessel sherds and lithic artifacts (debris from chipped stone tool manufacture and a single flake tool). These artifacts were collected from the surface of the site and from surrounding settlement/habitation deposits. The ceramic assemblage of sherds from plain ware, utility ware, and fine ware vessels are primarily grog-tempered, with considerable amounts of plain vessel rims and rim and body sherds from utility ware jars that are decorated with incised, punctated, brushed, and brushed-incised elements. Sherds from fine ware vessels are not well represented in the artifacts from the 2015 surface collection, but there are sherds from both engraved bottles and carinated bowls as well as red-slipped bowls. Decorative elements on the engraved sherds are consistent with earlier varieties of Poynor Engraved, the principal fine ware type in the upper Neches River basin beginning in the 15th century A.D. As with the collection of artifacts from the 1931 investigations completed by University of Texas archaeologists, these artifacts suggest that the Caddo occupation of the settlement at the M. S. Roberts site took place sometime as early as in the first half of the 15th century A.D., and the occupation may have lasted until as late as ca. A.D. 1480, during the first part of the Frankston phase.

\section{ACKNOWLEDGMENTS}

We would like to thank the landowners, Mr. and Mrs. Jim Renfroe, Caddo Creek Club in Larue, Texas, for permission to access the M. S. Roberts site, and obtain a surface collection from it. We also appreciate their efforts to protect and preserve the site. Lance Trask prepared Figure 1 in this article. 


\section{REFERENCES CITED}

Jackson, A. T.

1936 A Perpetual Fire Site. Bulletin of the Texas Archeological and Paleontological Society 8:134-174.

Kleinschmidt, U. K. W.

1982 Review and Analysis of the A. C. Saunders Site, 41AN19, Anderson County, Texas. Master's thesis, Department of Anthropology, The University of Texas at Austin.

Pearce, J. E. and A. T. Jackson

1931 M. S. Roberts Farm, Henderson County, Texas Oct. 8 to Oct. 11, 1931. MS on file, Texas Archeological Research Laboratory, The University of Texas at Austin.

Perttula, T. K.

2011 The Ceramic Artifacts from the Lang Pasture Site (41AN38) and the Place of the Site within an Upper Neches River Basin Caddo Ceramic Tradition. In Archeological Investigations at the Lang Pasture Site (41AN38) in the Upper Neches River Basin of East Texas, assembled and edited by T. K. Perttula, D. B. Kelley, and R. A. Ricklis, pp. 145-320. Archeological Studies Program Report No. 129, Texas Department of Transportation, Environmental Affairs Division, Austin.

Perttula, T. K., with contributions from W. Troell

2016 The A. S. Mann (41HE7/41AN201) and M. S. Roberts (41HE8) Sites in the Upper Neches River Basin, Henderson County, Texas. Journal of Northeast Texas Archaeology 59, this volume.

Perttula, T. K., M. Walters, and B. Nelson

2011 Archeological Investigations at the Pace McDonald Site (41AN51): A Middle Caddo Mound Center in the Neches River Basin in East Texas. Special Publication No. 21. Friends of Northeast Texas Archaeology, Austin and Pittsburg.

Suhm, D. A. and E. B. Jelks (editors)

1962 Handbook of Texas Archeology: Type Descriptions. Special Publication No. 1, Texas Archeological Society, and Bulletin No. 4, Texas Memorial Museum, Austin. Reprinted in 2009, Gustav's Library, Davenport, Iowa. 